\title{
Family Health Support Center in the perspective of physicians and nurses
}

\author{
Núcleo de Apoio à Saúde da Família na perspectiva de médicos e enfermeiros \\ Núcleo de Apoyo a la Salud de la Familia en la perspectiva de médicos y enfermeros
}

\author{
Jaqueline Carvalho e Silva Sales ${ }^{1}$ (D) \\ Camilla de Oliveira Castelo Branco ${ }^{1}$ (1) \\ Jordana Fonseca Reis ${ }^{1}(1)$ \\ Polyana Norberta Mendes ${ }^{2}$ (1) \\ Fernando José Guedes da Silva Júnior ${ }^{1}[$ \\ Andreia Rodrigues Moura da Costa Valle ${ }^{2}[\mathbb{C}$
}

${ }^{1}$ Universidade Federal do Piauí, Departamento de Enfermagem. Teresina, PI, Brasil.

2 Universidade Federal do Piauí, Programa de Pós-Graduação em Enfermagem. Teresina, PI. Brasil.

Corresponding author:

Fernando José Guedes da Silva Júnior

E-mail: fernandoguedes@ufpi.edu.br

Submitted on $06 / 27 / 2019$.

Accepted on 09/12/2019.

DOI: 10.1590/2177-9465-EAN-2019-0179

\begin{abstract}
Objective: To analyze the physician's and nurse's perceptions about the actions developed by the Family Health Support Center (FHSC). Method: A qualitative study, conducted with 16 physicians and 23 nurses. Data was collected through interviews and submitted to thematic analysis. Results: Three categories emerged: The actions developed by the Family Health Support Center were positively perceived by Family Health Strategy (FHS) professionals; Tools that favor the integrality of the actions of the FHSC with the FHS; Obstacles perceived by the professionals of the Family Health Strategy for the development of the actions of the Family Health Support Center. Conclusions and implications for practice: The participant's perceptions are positive. They perceive the strength of the FHSC in its multi-professional character effected by teamwork and effective communication. However, they also point out the restriction of time and transportation as obstacles for the viability of actions.
\end{abstract}

Keywords: Unified Health System; Family Health Strategy; Public Health.

\section{Resumo}

Objetivo: Analisar a percepção de médicos e enfermeiros sobre as ações desenvolvidas pelo Núcleo de Apoio à Saúde da Família (NASF). Método: Estudo qualitativo, realizado com 16 médicos e 23 enfermeiros. Os dados foram coletados por meio de entrevistas e submetidos à análise temática. Resultados: Emergiram três categorias: Ações desenvolvidas pelo Núcleo de Apoio à Saúde da Família são percebidas de forma positiva pelos profissionais da Estratégia Saúde da Família (ESF); Ferramentas que favorecem a integralidade das ações do NASF com a ESF; Entraves percebidos pelos profissionais da Estratégia Saúde da Família para o desenvolvimento das ações do Núcleo de Apoio a Saúde da Família. Conclusões e implicações para prática: A percepção dos participantes é positiva. Percebem a potência do NASF em seu caráter multiprofissional efetivado pelo trabalho em equipe e pela comunicação efetiva. No entanto, apontam também como entraves a restrição de tempo e transporte para viabilização das ações.

Palavras-chave: Sistema Único de Saúde; Estratégia Saúde da Família; Saúde Pública.

\section{REsumen}

Objetivo: Analizar la percepción de médicos y enfermeros sobre las acciones desarrolladas por el Núcleo de Apoyo a la Salud de la Familia. Método: Estudio cualitativo, realizado con 16 médicos y 23 enfermeros. Los datos se recolectaron por medio de entrevistas y se sometieron a análisis temático. Resultados: Emergieron tres categorías: Las acciones desarrolladas por el Núcleo de Apoyo a la Salud de la Familia son percibidas de manera positiva por los profesionales de la Estrategia Salud de la Familia; Herramientas que favorecen la integralidad de las acciones del NASF con la ESF; Obstáculos percibidos por los profesionales de la Estrategia Salud de la Familia para el desarrollo de las acciones del Núcleo de Apoyo a la Salud de la Familia. Conclusiones e implicaciones para la práctica: La percepción de los participantes es positiva. Perciben el poder del NASF en su carácter multiprofesional efectuado por el trabajo en equipo y la comunicación efectiva. Sin embargo, también señalan como obstáculos la restricción de tiempo y transporte para que las acciones sean viables.

Palabras clave: Sistema Único de Salud; Estrategia de Salud Familiar; Salud Pública. 


\section{INTRODUCTION}

In recent years, the Family Health Strategy (FHS) expansion has marked an indisputable progress of the Unified Health System (Sistema Único de Saúde, SUS), since it appears as a space for changes in the care model. This advance in solving the Brazilian population's health problems, in the setting in which they live and establish their family relationships does not mean, however, that the ideal situation has been reached, but it represents progress in the health area. ${ }^{1}$

In his context, in order to broaden the scope of the actions of the FHS, as well as their resolution, the Family Health Support Centers (FHSCs) were created, which are being implemented throughout Brazil. They are composed of professionals from different areas of knowledge who act in an integrated manner and support professionals of the FHS teams, as well as working directly in matrix support to the teams of the units to which they are linked. ${ }^{2}$

Several support actions are developed by these professionals, including: case discussion, shared or non-shared clinic, joint construction of therapeutic projects, continuing education, interventions in the territory, intersect oral actions, prevention and health promotion, besides discussion of the teams' work process. ${ }^{3}$ The development of these actions is based on the integrality guideline, defined in three objects: the individual, the health practices and the organization of the health system. ${ }^{4}$

Numerous activities can be developed by the FHSC professionals. These are focused on integral and shared care with the FHS team, in addition to establishing longitudinally of care. ${ }^{3}$

Considering that FHSC is configured as a support service to the FHS, created in 2008 in Brazil, but which has shown an exponential increase of implementation in the SUS care network, this study will allow reflections on this theme, especially on the need of the comprehensiveness of the actions of the FHS professionals with those of the FHSC, highlighting the potentialities and difficulties for the implementation of this principle, which will be relevant to offer quality care to the user. ${ }^{3}$

Due to this scenario, the objective of this study was to analyze physician and nurses' perceptions about the actions developed by the Family Health Support Center.

\section{METHOD}

A descriptive study with a qualitative approach, developed in the 11 Basic Health Units (BHUs) (seven in the urban area and four in the rural one) which are supported by three Family Health Support Centers (FHSCs) of Teresina, Piauí, Brazil.

16 physicians and 23 nurses participated in the study. This research adopted the following as inclusion criteria: physicians and nurses of both genders, effective and working in the FHS that has received support from the FHSC for at least two months.
The following individuals were excluded: three physicians and one nurse who at the time of data collection were on vacation, one nurse for being a substitute, three physicians who were not present at the $\mathrm{BHU}$ at the time of the researchers' visit after two attempts to apply the instrument, two physicians and one nurse who worked for less than 2 months at the BHU. Thus, eight physicians and three nurses were excluded. It is noteworthy that, at the time of data collection, two Family Health teams did not have medical professionals.

Data collection was carried out from November 2017 to January 2018. An open interview script was used containing questions related to the perception of actions developed by FHSC, namely: what is your perception about the actions developed by the FHSC in this BHU? How has the integrality of the FHSC's actions occurred/completed with your Family Health $(\mathrm{FH})$ team? What are the difficulties/practicalities for the integrality of the FHSC's actions occur with your FH team?

The participants received detailed guidance on the study and, after signing the Free and Informed Consent Form (FICF), the interview script was applied in the offices (medical and nursing) of the BHU. Mp3 was used for recording these reports, as accepted by the participants, in order to reliably reproduce the answers provided during the interview for later transcription and data analysis. On average, the interviews lasted 30 minutes. Regarding the participants' identification, the letter E was assigned for nurses (from the Portuguese word "Enfermeiro") and $\mathrm{M}$ for physicians (from the Portuguese word "Médico"), in addition to the ordinal number of each interviewee.

For data analysis, the thematic analysis technique was used, which is divided into three stages: pre-analysis (transcription and organization of the interviews, fluctuating reading and constitution of the corpus), exploration of the material (coding, enumeration, classification and aggregation) and processing of the results obtained with interpretation, considering the proposed objective. Thus, the objective was to aggregate various statements in thematic classes or categories, which objectively favored data grouping, being exhaustive, exclusive, concrete and appropriate. ${ }^{5}$

According to the ethical principles guiding research involving human beings, provided in Resolutions No. 466/12 and No. 510/2016 from the National Health Council, ${ }^{6}$ this study was approved by the Research Ethics Committee of the Federal University of Piauí with opinion number 2,085,463.

\section{RESULTS}

After mapping the data obtained through the interview technique, convergent information thematic nuclei emerged to form three categories.

\section{The actions developed by the FHSC are positively perceived by the FHS professionals}

The professionals reported that the development of the FHSC actions is positive, as it favors teamwork, multi-professional practice, diversity of actions, cooperation and partnership between the FHS and FHSC teams. 
The FHSC is very important to the Strategy as it has skilled professionals from various areas who support it. (M1)

I think it's very important, they collaborate a lot. In our case, we have a physical educator, nutritionist, social worker, psychologist and physical therapist. Well, they have really helped a lot. (E1)

It is very constructive because we need a lot of referral, for example, to the psychologist, physiotherapist and it helps because the patient's treatment has to be multi-professional. (M8)

It greatly facilitates health team's activities with the FHSC. (M10)

I think it's important to have the FHSC and we need it in the FHS. There is a psychologist, there is a nutritionist, a physiotherapist. So joint actions are important for the best team performance. (E12)

The FHSC, here in the unit gives us good support, we see the need for referral and partnership with them. From multiprofessional care with the FHSC. (E13)

My perception is that the FHSC has only things to add to the $B H U$. They have been extremely helpful! (E2O)

The multi-professional formation of the FHSC team was considered positive, as it allows for the diversification of the actions developed, which enables a greater provision of services to the community assisted by family health teams, as can be observed in the statements below.

I have more contact with them in home care. Thus, visiting patients who are bedridden. (M16)

They participate a lot, help us a lot with dynamics, even in problem solving and we make visits with them. (E18)

The FHSC comes to give this support, so we can do mainly educational actions, which are extremely important for family health. The FHSC comes to perform these actions and to provide complementarity in relation to other professional activities. (E21)

Indeed, with the FHSC arrival this counter-reference has improved. (E22)

I have a very good view of the FHSC, they help me a lot. Whatever happens I run to them, I refer to them, I ask for a suggestion. They are always there to help. I like the FHSC so much! (M5)

From the above, the importance of establishing a harmonious and cooperative relationship between professionals of these services that make up Primary Care is also noted, so that it is possible to develop the attributions of the FHSC in partnership with the FHS as evidenced by the participants in the following statements.
It's a very good help it gives us. Because it integrates us more. It makes the user of the unit not having to leave his area for a treatment. (M4)

These are good actions, teamwork! A summation work, which is very good. (M9)

On my perception, the actions developed by the FHSC are very important! It happens that way, with a lot of commitment and summarizing are very necessary actions. I came into contact with the FHSC, so I always say that I don't live today, I don't work today without FHSC! It is very important; this relationship is very cool. (M11)

The actions are very good! Because he is with the patient, the patient does not have to move so that he can solve a problem. (E11)

They really develop support, as it is an assumption that they can support teams. They really contemplate all those guidelines and really support the teams. I feel supported by the FHSC! (M12)

It adds up a lot to this integrality with our family health team and only brings benefits to the community. (M15)

\section{Tools which favor the integrality of the FHSC's actions with the FHS}

To integrate the actions developed by the professionals of the FHSC with those of the FHS, the participants mentioned the following as tools that favor this process: the physical structure, entitled by them as a foothold, effective communication and activity sharing, according to the following speeches.

We have the privilege of the FHSC to work here in this $B H U$. This completeness is very effective indeed. We pass along the demands to them directly, there is no exchange, bureaucratic referrals, we talk directly with professionals most of the time and, thus, it is very easy, facilitates the action here both of this team, as well as on the other, precisely because we have the FHSC core here in this BHU. (M1)

One of the practicalities is their foothold here at our BHU. So every day, even if they have activity in other units, they pass by here on arrival and departure, so that facilitates contact, communication. Is very good to be in contact because they are present here and because we have many projects and they fit into those projects. (E15)

There is always someone from the FHSC here, so we are always doing this work together. Then the ease is that every now and then, we find a member here and that makes it easier. This programming they do with us, these are processes that facilitate the work. The FHSC is a center we can no longer see us without. They are complements of our actions. (E16) 
The easiest thing I think is that the FHSC team stays here. They are always here in our unit and this makes the service much easier, sometimes I send a patient today and sometimes he is attended today, his situation is resolved that day. (E23)

In the speeches below it can be observed that the communication among the professionals involved in user care was expressed by the participants as fundamental for the planning and development of joint actions. The interviewees also signal strategies used for this information exchange to occur, such as meetings between teams and the use of digital tools.

Sometimes the professional comes here atBHU or sometimes I talk to him on WhatsApp. In any case, we agree on how we can provide patient care according to the situation. (M3)

They come here, we talk when a case arises, we send a message. We also communicate through message. We have even created an FHSC group with my WhatsApp team so we can send information we think urgent. Communication is good! (E5)

Through meetings and messaging via WhatsApp we sometimes have a problem, we already have a group set up, so we exchange some information, set up a meeting and it's happening like this. (E6)

I think there is a lot of communication between the two teams, we communicate a lot. (E17)

We are always in touch also through the WhatsApp group and this helps a lot, because we have daily contact even having the monthly meeting contact. (E19)

The integrality of the actions between FHS physicians and nurses with the FHSC team was expressed at different times, from educational activities to shared clinical care, described in the following statements.

We make the planning of the needs brought by the Community Health Agents (CHAs) themselves. So if we find a need for a demand in the area, we schedule and they (FHSC) put it on their schedule. (E3)

There is joint venture. We have joint planning. They present their activity schedule, the propositions, and we also tailor our schedule to their activities. So it's in partnership. (M14) We discussed everything that the health agent discovered in the area during the week and will plan joint actions that we will take in relation to these problems. (M7)

They make the care attention, we schedule the patients for them. They forward, we visit together, we attend, it is collective, collective activities, everything we need they are together with us. (E9)
We work on a scheduled basis with them. We refer and schedule patients and we also do shared care! We give lectures, we do allusive, educational activities. It is quite potent and effective. (E10)

\section{Obstacles perceived by the FHS professionals for the development of the FHSC actions}

This category addresses the obstacles perceived by the professionals for the integration between the actions they developed and the professionals of the FHSC. These obstacles range from the time availability of the FHSC members to each supported $\mathrm{BHU}$ to the transportation constraints for the FHSC staff moving to the BHU.

The difficulty is the time the professionals of the FHSC have to serve the entire community for which they are responsible. (E2)

Since the FHSC is not unique to this unit, they have a very short time and this schedule is not yet set, so this makes it difficult. (E4)

It's not enough! If I had more time, it would be better. Because it gave them more, time to come to the basic units that they were responsible for. (M2)

Since you have an FHSC team to service multiple BHUs, so time is limited. So many actions that might have better involvement or greater attention cannot be done because you have to distribute that attention to the other units. (M13)

The only difficulty I see is their time! Because there are so many teams to support, I think there are 9 teams, so they have little time to dedicate to each team. (E14)

For the development of the shared activities between the FHSC and FHS team, it is necessary to use transportation. However, lack of transport availability, when necessary, was listed as an obstacle to the development of actions by both services.

One of the biggest difficulties is that we do not always have easy transportation. Lately the Municipal Health Foundation (MHF) has limited the coming of the support car. (M6) The difficulty is that sometimes we plan something and they don't come when we plan because of the car issue. Because the car is never there when we schedule the actions. They always arrive, sometimes later, when the car doesn't come to do the action. (E7)

The transportation issue, sometimes we want to give a talk. There is no transport to pick them up. Sometimes their car is late and they don't arrive on time because of the car. (E8) 


\section{DISCUSSION}

In the speeches it is observed that the positive view of the physicians and nurses of the FHS is related to the multiprofessional characteristic in the composition of the FHSC team. This factor is linked to the significant contribution in the scope of the complementarity of the actions in the FHS, especially regarding to the need for specialized care, as this increases the FHS's scope of action and, thus, the resoluteness of the problems faced by population.

The multi-professional composition of the FHSC team has supported and strengthened the actions developed by the FHS professionals, as well as assisting in the organization of the service offered, since it reduces the waiting lines for specialized care, following the evolution of the health care models that seek integral, shared and resolute attention. ${ }^{7-8}$

This multi-professionalism enables knowledge exchange among various areas, which seeks to share knowledge related to the performance of each professional to, consequently, offer comprehensive care. It is noteworthy that knowledge exchange is an indispensable tool for improving daily teamwork work, especially regarding integration, as it creates a bridge between knowledge, reflection and action, and broadens interventions. This feature portrays the FHSC's work methodology based on the pedagogical technical support, known as matrix support. ${ }^{4}$

In addition, although the FHSC team is composed of professionals from different areas and develops an integrated work process, it is necessary to preserve the peculiarities of each profession, in order to avoid an idea of generic team performance, a fact that it would decharacterize the main purpose of sharing, discussing and thus solving problems of the individual, family and community in the area where the center operates and the teams it supports. ${ }^{9}$

Therefore, the diversity of actions developed by the FHSC was also mentioned by the participants of the present study as a positive point, since it impacts the way of taking care of the individual and the family by promoting considerable changes in the health-disease process, from the development of health promotion actions, home visits, forwarding, as well as referral and counter-referral.

In this sense, the increase in the users' demand for Primary Care health services is a result of thee reception's operationalization, of the expansion of service provision and of the problem solving power through the articulation of the FHSC and the FHS, which has enabled the provision of integral and humanized care. ${ }^{9}$
One of the actions taken by the FHSC and mentioned by the participants was the development of educational activities, pillar of action in the FHS. This activity consolidates the development of a health model that is not disease-centered, but focused on identifying the population's empowerment possibilities in relation to their own health care, according to the context in which they are inserted, which influences the reduction of care demand in the $\mathrm{BHU}$, as well as optimizing the care process. ${ }^{7}$

The Home Visit (HV), also cited as an example of an activity performed by the professionals of the FHSC, enables closer relationships between both teams, the individual and the family, while it gives access to social determinants, such as the family context, housing conditions, housing dynamics and family illness patterns. These characteristics help to draw up a shared care plan, as well as to direct the activities to encourage self-care. ${ }^{10}$

Another noteworthy action was direct referrals, those that do not need a bureaucratic, often tiring and time consuming process, such as appointment scheduling on-line, because the professionals of the FHSC attend the BHUs, which are regularly linked. This proximity allows a rapid and effective feedback among these professionals on the monitoring of the assisted demand and to evaluate determinants for progression or regression of the therapeutic follow-up, a characteristic mentioned by professionals with regard to effective counterreferral. However, it should not be forgotten that the FHSC does not act as a gateway to the health system; although it is directly linked to the FHS, the request must be directed from the $\mathrm{BHU}{ }^{7}$

In addition, the testimonies identify the partnership between the professionals of the FHS and those of the FHSC. The participants justify the importance of this factor for the positive perception they have regarding the FHSC, especially for the support, integration, resoluteness and backup from this relationship, as well as the improvement in the scope of services provided.

A study conducted in Fortaleza-Ceará pointed out that the cooperation between FHSC and FHS professionals occurs mainly due to the good relationship they established throughout the work process, which facilitates knowledge sharing during care and, consequently, the provision of comprehensive care. ${ }^{9}$

Teamwork presupposes collaboration establishment, integration and partnership to achieve the objectives in a satisfactory way, which enables the exchange of knowledge by the professionals involved, a factor that positively impacts the provision of care, in the expansion of the service offered and greater resoluteness of the problems faced. ${ }^{11}$ 
In addition, from the foregoing reports, it is understood that since the $\mathrm{BHU}$ is located in the community assisted by both the FHS and FHSC, this location is understood as a "foothold" of core professionals and this configuration is referred to by interviewees as beneficial in the way that it allows them to be closer to each other and provides opportunities for sharing activities.

However, it is noteworthy that the FHSC does not have its own facilities, so it uses the BHU's facilities where the FHS team works, without having to maintain the core components fixed in these facilities, as the FHSC works as a complementary support to the various $\mathrm{BHUs}$ covering different territories. Thus, it is understood that the FHSC should also develop activities outside this physical structure, in places where assisted communities live, developing actions for health prevention, promotion and protection. ${ }^{3}$

Another important aspect considered for the integrality of actions is communication. According to the interviewees, this feature is indispensable for the establishment of comprehensive care, regardless of the location, because through communication it is possible to know the clients' individualities and needs, as well as the family and social context in which they are inserted, which will contribute to improving the provision of assistance. ${ }^{12}$

In this perspective, sharing information becomes fundamental among the teams involved in health care and should occur in a way that allows its effectiveness. A research conducted in Campina Grande-Paraíba showed that communication is a strategy that promotes a link between the teams involved in caring, can be exercised during meetings, which are characterized as important moments for sharing, planning activities and aims at the integrality of actions among different services. ${ }^{13}$

In fact, the meetings are characterized as spaces for the information exchange among the actors involved in care; however, with the emergence and advancement of technology, professionals have used other means of communication, such as digital ones. The incorporation of new health communication technologies, such as WhatsApp and text messaging, have favored the exchange of information in a more interactive way, allowed for a greater flow of updates in a shorter time and also for the collaboration among the involved parties, thus being configured as a value element for the expansion of communication channels in this scenario. ${ }^{10}$

It can be observed that the joint planning of activities, as well as the adequacy of these activities in the schedules of the FHSC and FHS teams has favored the integrality of the actions. The shared activities expressed by the deponents were clinical care, home visits, educational activities and referrals. In this sense, case discussions, clinical care, home visits and health education are activities developed jointly by the FHSC and FHS professionals, and have favored the integrality of the actions offered to the clients of the assigned territory, besides the exchange of knowledge among the actors of these services.
This work model helps to the extent that it provides a common setting, which is characterized by being favorable to the development of stronger partnerships between the teams involved, by closer relations with the sharing of actions developed. ${ }^{14}$

It is noteworthy that the FHSC performs its activities based on matrixing, which consists in providing support, as well as technical-pedagogical support, from specialized teams to reference generalists, exemplified here by the FHS.4 Thus, the FHSC's work proposal is focused on the co-responsibility of health care, sharing activities between the FHSC and FHS teams that should be guided in the union of knowledge, skills and experiences, as well as in the partnership and horizontality of the actions. ${ }^{15}$

Moreover, it is observed in the speeches that the available time by the professionals of the FHSC is a limiting factor for the development of shared actions between them and the members of the FHS. Time constraints for the respondents directly affect the FHSC's provision of care to the community, their involvement in shared health care activities, and the interaction between teams.

It should be noted that, although the speeches emphasize the obstacles, these perceptions show limitations regarding the knowledge of the FHSC's operating guidelines. The development of the FHS teams' activities has followed the traditional referral arrangement, in which the FHSC acts as a reference and not as support, backup and sharing of actions. This perspective diverts one of the focal points of the FHSC's action towards the FHS, namely: co-responsibility, a factor that impacts on the understanding of the FHSC availability and resoluteness in relation to the demand to be met. ${ }^{16}$

This statement is supported by a study which identified that the FHSC professionals had their working time affected due to the large amount of specialized care, among which individual referrals stood out, mainly. ${ }^{17}$ There is a limiting perception about the support offered by the FHSC team, since the partnership that exists with the FHS members should seek to reaffirm the $B C$ guidelines through action sharing, prioritizing the collective approach.

The FHSCs can be classified into three types $(1,2$ and3) and are differentiated by the number of FHS teams they support. ${ }^{18}$ Thus, the lack of this clarification has raised questions regarding the mentioned distribution, especially regarding the lack of exclusivity of an FHSC team for each existing FHS team in the municipalities that receive this service related to the time dedication factor. ${ }^{15}$

In parallel to the issue of the time constraint the FHSC professionals can avail to the BHU they support, deponents added the great territorial demand to this difficulty. 
It is noteworthy that the more the FHS and FHSC teams are available to give support more families should be assisted since, by the National Primary Care Policy (Política Nacional de Atenção Básica, PNAB), each FHS team should accompany up to one thousand families, which corresponds to an average of 3,500 people. $^{2}$

It is necessary that the FHS professionals understand about the philosophy of action of the FHSC, which has sought the sharing of actions between these services from the matrix support. Thus, the FHS will be able to solve most of the health problems of its community, configuring itself as the first level of SUS care, and will relieve the other levels of health care, such as the tertiary. ${ }^{19}$

A research conducted in the city of São Paulo showed that the FHSC teams worked with therapeutic, thematic and educational groups, most often in partnership with FHS professionals, and achieved positive results related to the improvement in the quality of life of the individuals, families and communities they assist. ${ }^{17}$

Regarding transportation, the lack or insufficient number of vehicles was highlighted as a factor that hinders the development of activities in a timely manner by the FHSC and FHS professionals. In addition, this difficulty, related to transportation, has affected the performance of actions outside the BHU, such as in academy centers in the square, the Health at School Program (Programa Saúde na Escola, PSE), home visits, and educational activities, among others.

The insufficient transportation provided by the municipalities has directly affected the service provided by the FHSC and FHS teams, since the BHU's geographical accessibility often does not cooperate,; thus, the homes of some families are distant and difficult to access, making it imperative to provide public transportation. This problem has negatively affected the development and sharing of actions by these services, which has generated discredit on the part of the assisted population, which often sets aside time from their daily tasks to participate in previously disclosed activities, but they do not happen. ${ }^{20}$

It is emphasized that the manager must have conditions for the displacement of professionals from the FHSC and FHS teams or allowances or transportation vouchers, when necessary, so that the activities planned by these services can be carried out to the assisted community. ${ }^{2}$

\section{CONCLUSION AND IMPLICATIONS FOR THE PRACTICE}

Physicians and nurses' perceptions about the actions developed by the FHSC are positive and are related to the multi-professional character of teamwork, which is permeated by effective communication among peers. The professionals report that for the full professional exercise, communication between teams, although informally, through the incorporation of digital tools, has favored multi-professional cooperation.
Some factors were mentioned as key points for the integrality of the work between the FHS and the FHSC: the diversification of the activities developed, as well as the prioritization of the sharing of these actions (joint care, home visits, and health education activities). The existence of the FHSC's foothold in a BHU made it possible for teams to get closer. Barriers to the integrality of actions were also reported: the time available for each supported team, the demand to be assisted and the restriction of transportation for the FHSC team to reach the BHU.

A limitation of this study is the methodological approach itself that does not allow generalizations, since the perceptions are unique to each participant. Given the above, the work in question highlighted points for establishing a bond and sharing actions between the FHSC and FHS professionals. Thus, this research seeks to stimulate the development of future similar studies in the scope of BC, as well as contribute to improvements, in relation to the obstacles listed, with a view to bringing benefits to the assistance.

\section{REFERENCES}

1. Brito GEG, Mendes ACG, Santos Neto PM. Purpose of work in the Family Health Strategy. Interface [Internet]. 2018 mar; [cited 2019 may 02]; 22(64):77-86. Available from: http://dx.doi.org/10.1590/180757622016.0672

2. Ministério da Saúde (BR). Portaria de Consolidação n. 2, de 28 de setembro de 2017. Aprova a Consolidação das normas sobre as políticas nacionais de saúde do Sistema Único de Saúde. Brasília (DF): Ministério da Saúde; 2017

3. Ministério da Saúde (BR). Secretaria de Atenção à Saúde. Departamento de Atenção Básica. Cadernos de Atenção Básica, n. 39. Núcleo de Apoio à Saúde da Família - Ferramentas para a gestão e para o trabalho cotidiano. Brasília (DF): Ministério da Saúde; 2014

4. Reis MI, Medeiros M, Pacheco LR, Caixeta CC. Avaliação do trabalho multiprofissional do Núcleo de Apoio à Saúde da Família (NASF). Texto Contexto - Enferm [Internet]. 2016; [cited 2019 may 02]; 25(1):e2810014 Available from: http://dx.doi.org/10.1590/0104-070720160002810014

5. Minayo MCS. Pesquisa Social: teoria, método e criatividade. $30^{\text {a }}$ ed Rio de Janeiro: Vozes; 2011

6. Ministério da Saúde (BR). Conselho Nacional de Saúde. Resolução n 466, de 12 de dezembro de 2012. Brasília (DF): Ministério da Saúde 2012; [cited 2014 jul 31]. Available from: https://bvsms.saude.gov.br/ bvs/saudelegis/cns/2013/res0466_12_12_2012.htm

7. Souza FLD, Chacur EP, Rabelo MRG, Silva LAM, Villela WV. Implementation of the Family Health Support Units: the user's perception. Saúde Debate [Internet]. 2013 jun; [cited 2019 may 08]; 37(97):233-240. Available from: http://www.scielo.br/scielo.php?script=sci_arttext\&pid=S0103$-11042013000200005 \&$ Ing $=e n$

8. Nascimento DDG, Quevedo MP, Oliveira MAC. O prazer no trabalho no núcleo de apoio à saúde da família: uma análise Dejouriana. Texto Contexto-Enferm [Internet]. 2017; [cited 2019 may 04];26(1):e6380015 Available from: http://dx.doi.org/10.1590/0104-07072017006380015

9. Macedo MV, Ximenes-Guimarães J, Coelho-Sampaio J, Pereira-Morais A, Carneiro $C$. Análise do processo de trabalho no núcleo de apoio à saúde da família em município do nordeste brasileiro. Gerenc Polít Salud [Internet]. 2016 jun; [cited 2019 may 08]; 15(30):194-211. Available from: http://dx.doi.org/10.11144/Javeriana.rgyps15-30.aptn

10. Santos RABG, Uchôa-Figueiredo LR, Lima LC. Matrix support and actions on primary care: experience of professionals at ESF and NASF. Saúde Debate. [Internet]. 2017 sep; [cited 2019 may 22]; 41(114):694706. Available from: http://dx.doi.org/10.1590/0103-1104201711402 
11. Hirdes A. A perspectiva dos profissionais da atenção primária à saúde sobre o apoio matricial em Saúde mental. Cien Saúde Coletiva [Internet]. 2015 feb; [cited 2019 jun 02]; 20(2):371-382. Available from: http://dx.doi.org/10.1590/1413-81232015202.11122014

12. Tesser CD. Núcleos de Apoio à Saúde da Família, seus potenciais e entraves: uma interpretação a partir da atenção primária à saúde. Interface (Botucatu) [Internet]. 2017 sep; [cited 2019 may 21]; 21(62):565-578. Available from: http://dx.doi.org/10.1590/180757622015.0939

13. Brandão GCG, Oliveira MAC. $O$ trabalho em equipe em unidades da estratégia saúde da família de um município paraibano. RSC Rev Saúde Ciência [Internet]. 2016; [cited 2017 nov 31];5(3):51-62. Available from: http://www.ufcg.edu.br/revistasaudeeciencia/index.php/RSC-UFCG/ article/view/406/260

14. Nakamura CA, Leite SN. Construction of the work process of the Family Health Support Nucleus: the experience of pharmacists in a city in the south of Brazil. Ciên Saúde Coletiva [Internet]. 2016 may; [cited 2019 may 22];21(5):1565-72. Available from: http://dx.doi.org/10.1590/141381232015215.17412014

15. Shimizu HE, Fragelli TBO. Core Competencies for Working in the Family Health Support Group. Rev Bras Educ Med [Internet]. 2016 jun; [cited 2019 jun 02]; 40(2):216-25. Available from: http://dx.doi. org/10.1590/1981-52712015v40n2e02702014
16. Oliveira IF, Amorim KMO, Paiva RA, Oliveira KSA, Nascimento MNC, Araújo RL. The Role of the Psychologist in NASF: Challenges and Perspectives in Primary Health Care. Temas Psicol [Internet]. 2017 mar; [cited 2019 jun 02]; 25(1):291-304. Available from: http://dx.doi.org/10.9788/TP2017.1-17Pt

17. Gonçalves RMA, Lancman S, Sznelwar LI, Cordone NG, Barros JO. Estudo do trabalho em Núcleos de Apoio à Saúde da Família (NASF), São Paulo, Brasil. Rev Bras Saúde Ocup [Internet]. 2015 jun; [cited 2019 jun 02]; 40(131):59-74. Available from: http://dx.doi.org/10.1590/03037657000078013

18. Ministério da Saúde (BR). Portaria n. 3.124, de 28 de dezembro de 2012 Redefine os parâmetros de vinculação dos Núcleos de Apoio à Saúde da Família (NASF) Modalidades 1 e 2 às Equipes Saúde da Família e/ ou Equipes de Atenção Básica para populações específicas, cria a Modalidade NASF 3 , e dá outras providências. Brasília (DF): Ministério da Saúde;2012; [cited 2015 jul 31]. Available from: http://bvsms.saude. gov.br/bvs/saudelegis/gm/2012/prt3124_28_12_2012.html

19. Correia PCl, Goulart PM, Furtado JP. A avaliabilidade dos Núcleos de Apoio à Saúde da Família (Nasf). Saúde Debate [Internet]. 2017; [cited 2019 jun 02]; 41(spe):345-59. Available from: http://dx.doi. org/10.1590/0103-11042017s25

20. Viegas APB, Carmo RF, Luz ZMP.Factors associated to the access to health services from the point of view of professionals and users of basic reference unit. Saúde Soc [Internet]. 2015 mar; [cited 2019 jun 02]; 24(1):100-12. Available from: http://dx.doi.org/10.1590/S0104-12902015000100008 